Article

\title{
Performance Assessment of a Hybrid Vapor Compression and Evaporative Cooling Fresh-Air-Handling Unit Operating in Hot Climates
}

\author{
Yousef Al Horr *, Bourhan Tashtoush, Nelson Chilengwe and Mohamed Musthafa \\ Gulf Organisation for Research and Development, Qatar Science and Technology Park, P.O. Box 210162 Doha, \\ Qatar; b.taschtouch@gord.qa (B.T.); n.chilengwe@gord.qa (N.C.); m.musthafa@gord.qa (M.M.) \\ * Correspondence: alhorr@gord.qa
}

Received: 25 September 2019; Accepted: 19 November 2019; Published: 21 November 2019

\begin{abstract}
Evaporative cooling can be integrated into fresh-air-handling units, to reduce cooling demand. This study considers a hybrid fresh-air-handling unit which incorporates a vapor-compression cooling cycle and indirect evaporative cooling to condition an ambient primary airstream to a desired supply air state. The cooling effects of using various modes (vapor compression only; direct expansion with mist; direct expansion with water shower; and direct expansion with mist and water shower) are compared when the fresh-air-handling unit operates in harsh (hot and humid) climatic conditions experienced in Qatar. Experimental analysis is based on actual ambient conditions measured from August 2018 to July 2019. It is found that the best-performing wet mode of operation saves more than $60 \%$ of the energy required by a conventional direct expansion cooling system operating under the same ambient conditions. In hot, dry conditions, the coefficient of performance of the fresh-air-handling unit when using the indirect evaporative mode of operation is double the coefficient of performance when operating with direct expansion mode only.
\end{abstract}

Keywords: cooling performance; energy savings; hot and humid climate; indirect evaporative cooling; mode of operation

\section{Introduction}

Middle East countries use vast quantities of energy to cool buildings all year round. A large proportion of this consumption is associated with the residential sector for which air conditioning accounts for approximately 70\% [1] of the buildings' energy consumption. Various measures aimed at reducing this energy consumption can help mitigate against the region's sustainability challenges. Evaporative cooling is one such measure that can be integrated into fresh-air-handling units, to reduce cooling demand, and it can effectively provide free cooling when ambient conditions permit. Evaporative cooling can be achieved by using different modes of operation, most commonly mist injection [2,3], water spray [4,5], or a combination of mist and water shower. For an air-handling unit that integrates evaporative cooling technology, the cooling performance can be optimized by configuring the control system to switch the mode of operation accordingly, to suit ambient conditions occurring at a given time.

Evaporative cooling technology is deemed to provide cooling energy-saving and has a beneficial impact on the environment, which is gained by minimization of the adverse effects contributing to climate change. Evaporative cooling has been studied widely across the world. Kulkarni et al. [6], from a study of evaporative cooling in major cities in Asian, concluded that it has excellent potential to replace conventional air conditioning and that it can deliver better air quality. Al-Juwayhel et al. [7] considered four different configurations of evaporative air coolers operating under a hot summer 
experienced in Kuwait and characterized cooling performance by using thermal effectiveness and energy efficiency ratio. In their experimental evaluation investigations undertaken on a multistage evaporative cooling system, the authors managed to extend the cooling range of an indirect/direct evaporative cooling (IDEC) unit by adding a mechanical vapor-compression unit. The resulting system achieved ambient-to-supply air temperature reductions of up to $25^{\circ} \mathrm{C}$.

De Antonellis et al. [8] considered indirect evaporative cooling as a suitable way to improve the energy efficiency of an air-conditioning system. In their investigations on evaporative cooling, Suryawanshi et al. [9] reported that a two-stage evaporative cooling system was 4.5 times better, in terms of efficiency, compared to a traditional air conditioning unit. Indirect evaporative coolers can be integrated into air-handling systems, to improve energy efficiency. De Antonellis et al. [10] showed that indirect evaporative cooling could deliver large cooling capacities in many operating conditions.

The conventional vapor compression refrigeration cycles are widely used in air-conditioning systems. However, their use is associated with high energy consumption required to drive the compressor, and the use of refrigerants negatively impacts the environment. Many researchers have studied modifications on vapor-compression refrigeration cycles, to reduce electrical energy consumption and enhance the performance of the machine. For instance, measures are taken by introducing an ejector to the refrigeration cycle and utilize waste heat from the condenser [11,12].

Evaporative cooling units, when combined with traditional cooling systems utilizing refrigerant-based vapor-compression cooling cycles can provide more efficient hybrid cooling systems. Such hybrid systems enable evaporative cooling units to perform more effectively in humid climatic conditions, as cited in a study by Cui et al. [13], with results showing the integrated unit has great potential to reduce electrical demand, as well as energy usage.

Another approach to reduce electrical energy consumption is to replace the compressor by an ejector which can be driven by low-grade heat, such as solar energy [14,15]. Furthermore, hybrid systems have been investigated where combined power and refrigeration is introduced. Solar energy is the driving force for such systems that simultaneously generate power and cooling effects $[16,17]$.

Heidarinejad et al. [18], in their work involving a two-stage IDEC unit operating under Iranian climatic conditions, reported electrical energy savings of $60 \%$ compared to a mechanical vapor-compression system. They also observed that the hybrid mode consumed required $55 \%$ more water than when using only the direct evaporative cooling configuration.

Chauhan et al. [19] analyzed a hybrid evaporative/vapor compression system for arid climatic conditions, and their results showed energy savings over $64 \%$ compared to a conventional vapor compression system. Kim et al. [20] also evaluated the cooling energy performance of a 100\% fresh-air system utilizing a direct expansion cooling coil and integrating indirect-direct evaporative coolers. They indicated that their system saved 51\% energy compared to a traditional variable air volume system.

The main electrical consuming elements in ventilation systems incorporating evaporative cooling components are the supply and extract fans, water pumps, and direct expansion/mechanical vapor compressor. Some research studies have reported electrical energy consumption associated with their systems. For instance, Bruno [21] conducted on-site experimental testing to analyze potential energy savings of using a dew-point evaporative cooler in a commercial building application and found that the system delivered $52 \%-56 \%$ energy savings, also noting that, on days when the maximum temperature was higher than $35^{\circ} \mathrm{C}$, the average energy efficiency ratio (cooling capacity produced divided by the associated electrical power input) of their system was 7.2-11.5. Porumb et al. [22] studied a fresh-air-handling hybrid system incorporating evaporative cooling and found that electrical energy demand was reduced by $80 \%$, as well as a reduction of the total cooling load by approximately $84 \%$, compared to a conventional vapor-compression system.

Maheshwari et al. [23] carried out an analytical evaluation of an indirect evaporative cooling unit and found that it consumed 3.5 times less energy compared to a traditional packaged air-conditioning unit. Results from experimental investigations, by Delfani et al. [24], on an indirect evaporative cooler used as a precooling unit for a mechanical cooling system showed electrical energy savings of $55 \%$, 
and cooling-load reductions of up to $75 \%$, compared to a packaged air-conditioning unit. It is essential to understand how a hybrid air-conditioning system performs not only at design conditions but in a variety of ambient conditions, too. A few studies have reported such assessments. For instance, a study by Chauhan et al. [25] showed that a combined dew-point evaporative-vapor-compression air-conditioning unit gave energy savings of $55 \%$ better, and a saving of cooling load of $61 \%$ when operating in hot, dry conditions compared to dry and moderately humid conditions. Solar adsorption and absorption cooling have been widely investigated to utilize renewable energy to cover the cooling demand in air-conditioning applications.

Many studies have singled out and highlighted the main disadvantage of evaporative cooling as its water consumption. In evaporative cooling systems, water is usually recirculated, and this leads to losses due to evaporation. It was found that the evaporative losses can account for as much as $15 \%-20 \%$ of the water used each day $[26,27]$. Other researchers have analyzed and quantified water consumption for evaporative cooling purposes $[8,28]$ and found that certain water flowrates improved the cooling performance of their systems.

Liberati et al. [29] investigated indirect evaporative cooling (IEC) and report that the cooling capacity of their evaporatively cooled system doubled, compared to dry mode operation, when the heat exchanger was sprayed with only $15 \mathrm{~L} \cdot \mathrm{h}^{-1}$. The behavior of water nozzles and airflow arrangements has been studied, for instance, De Antonellis et al. [30], how these affect the cooling performance of a crossflow indirect evaporative cooler. Farnham et al. [31] studied the effect of the temperature of the mist spray. They report that the evaporation rate of the mist spray was enhanced when the temperature of the water increased.

The use of IEC to precool fresh air has been investigated [32], and several researchers have investigated the cooling performance of EC systems in a variety of climates [33-35]. Also, some researchers have considered the cooling performance of IEC in hot and humid climatic regions [36], such as those experienced in the Middle East.

Studies to modify and enhance conventional cooling systems using hybrid cycles investigated here contribute to desirable solutions that minimize the air-conditioning electrical load imposed on a national grid, and these solutions contribute to reduction of harmful greenhouse gas emissions.

The present study assesses the performance of a hybrid fresh-air-handling cooling system integrating IEC heat exchanger used in combination with a direct expansion cooling coil and operating in various modes against harsh climatic ambient conditions experienced in Qatar. The system investigated has a cooling capacity of $80 \mathrm{~kW}$ and a rated electrical energy consumption of $18 \mathrm{kWh}$. The study considers the cooling performance of the FAHU based on temperature reductions across the crossflow heat exchanger and direct expansion (DX) cooling coil, as well as the energy consumption of the various modes of operation which are analyzed based on actual data acquired via experimental measurements during the period August 2018 to July 2019. There seems to be a lack of studies in the existing literature of investigations relating to the integration of cooling performance and operating mode assessments of hybrid evaporative cooling units working under diverse ambient conditions. Therefore, the work in the present study is targeted toward addressing this gap in available information.

\section{Experimental Setup}

\subsection{System Construction and Description}

Experiments, using the fresh-air-handling unit (FAHU) test rig, shown in Figure 1, were carried out at GORD's Technohub premises in Doha, Qatar. A schematic diagram of the experimental test rig is shown in Figure 2. In the wet modes of operation, the primary air-supply air through the FAHU is initially cooled by indirect evaporative cooling (IEC) in the dry channels of the crossflow heat exchanger. Additional or supplemental cooling of the primary supply air is provided by direct cooling, using a DX cooling coil, i.e., the evaporator of the mechanical refrigeration system within the FAHU. The secondary airflow, initially at ambient conditions, is drawn into the FAHU, where it is 
preconditioned with mist injection. The secondary airstream is then sprayed with a water shower before it flows through the wet channels of the crossflow heat exchanger, where it cools the primary air by indirect evaporative cooling. When the FAHU operates in dry mode, neither mist injection nor water shower is used.

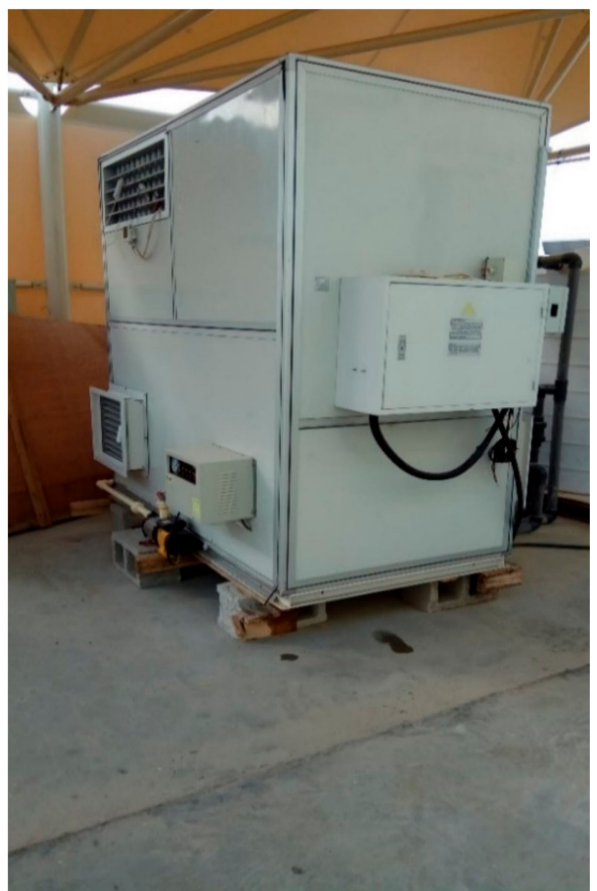

(a)Front Side of the UNIT

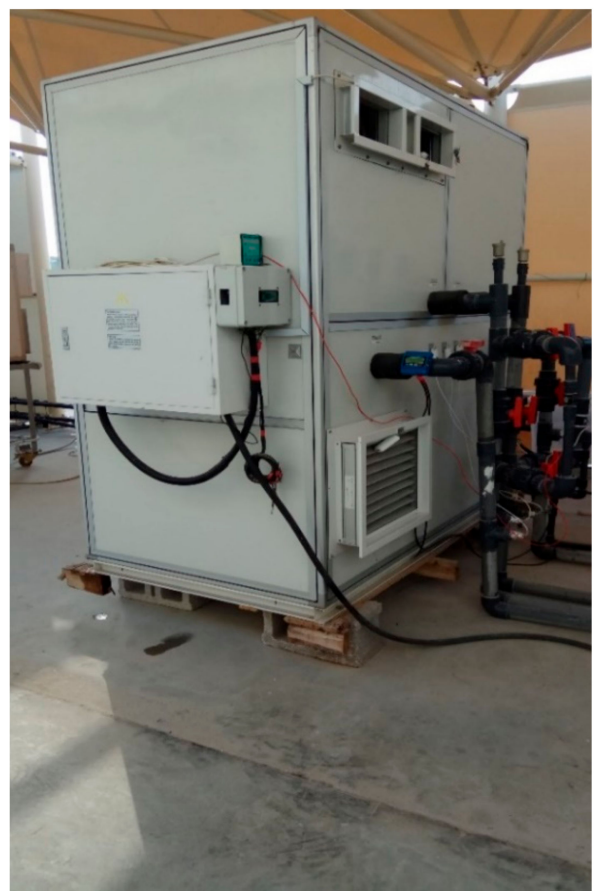

(b)Back side of the Unit

Figure 1. Experimental setup at GORD TechnoHub Doha, Qatar.

The schematic presentation of the experimental setup also shows key locations of measurement sensors, number 1-7. These sensors are used to measure temperature and humidity and transfer the acquired data continuously by wireless technology to GORD's computer server. The main parameters of the FAHU and measurement sensors are given in Table 1 below.

Table 1. Key parameters of fresh-air-handling unit (FAHU) test rig.

\begin{tabular}{|c|c|}
\hline Supply airflow rate & $1.4 \mathrm{~m}^{3} \mathrm{~s}^{-1}$ (Rated) \\
\hline Extract airflow rate & $1.4 \mathrm{~m}^{3} \mathrm{~s}^{-1}$ (Rated) \\
\hline DX Evaporator & 6 row coil, flow rate: \\
\hline Condenser & Cooled by secondary airstream \\
\hline Plate heat exchanger & $\begin{array}{c}\text { Crossflow type, } \mathrm{A}=0.119 \mathrm{~m}^{2}, \text { plate thickness }=0.15 \mathrm{~mm}, \\
\text { plate conductivity }=220 \mathrm{Wmk}^{-1}, 125 \text { plates }\end{array}$ \\
\hline Ultrasonic mist generator & $\begin{array}{l}\text { Mist Generation-0.005 L } \cdot \mathrm{s}^{-1}, \text { Power }-0.75 \mathrm{~kW} \\
\text { Tank Dimension- } 0.18 \times 0.24 \times 0.7 \mathrm{~m}\end{array}$ \\
\hline Water pump P1 & $0.042 \mathrm{~L} \cdot \mathrm{s}^{-1}$ \\
\hline Water pump P2 & $0.34 \mathrm{~L} \cdot \mathrm{s}^{-1}$ at $44 \mathrm{~m}$ head \\
\hline Measurement sensors & $\begin{array}{c}\text { Aranet } 4-20 \mathrm{~mA} \text { Current sensor. Measurement accuracy } \pm 0.5 \% \text {. } \\
\text { Range: }-40 \text { to } 60^{\circ} \mathrm{C}, 0 \% \text { to } 100 \% \mathrm{RH} \text {. }\end{array}$ \\
\hline
\end{tabular}




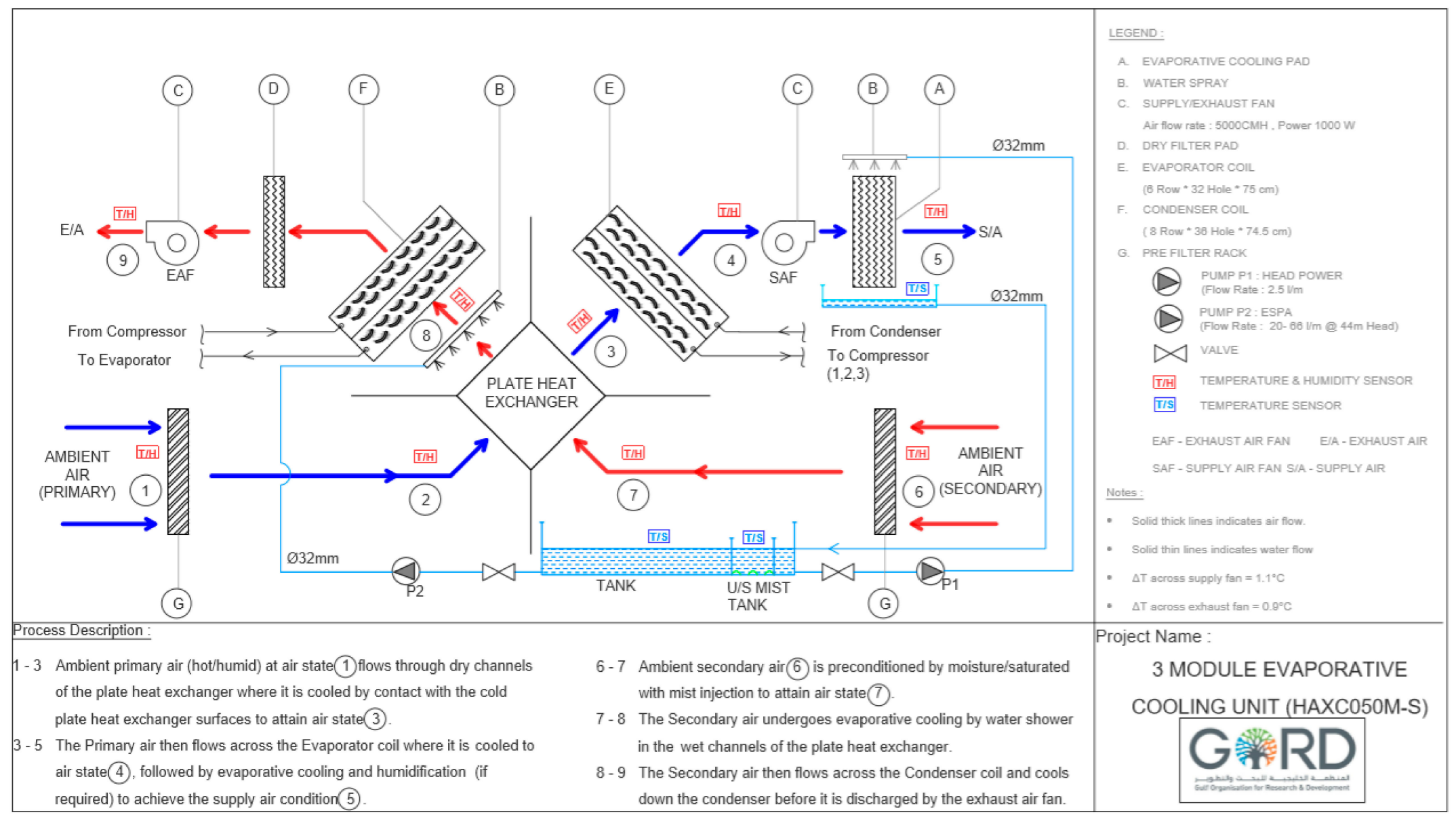

Figure 2. Schematic diagram of experimental test rig. 
The supply and extract airflow rates were verified by taking an array of air velocities (12 readings for each duct) across the fan outlet ducts. The product of the average velocity (supply of exhaust) and the associated geometrical area of the rectangular outlet duct gives the air-volume flow rate of the fan.

It can be seen from Figure 2 that there is a dry filter pad located on the downstream of the air-cooled condenser. The purpose of the filter pad is to trap any water droplets carried over from the water shower nozzles and prevent the water droplets from accumulating in the exhaust-fan casing.

In this study, it is assumed that the wet channels of the plate heat exchanger are thoroughly wetted by the water shower when it is in use. Although the FAHU surfaces are internally insulated where possible, there may likely be heat exchange between surfaces at different temperatures within the FAHU. These, together with any undesirable heat exchanges between airstreams, are neglected for this study. It is also assumed that there is no infiltration/air leakage through imperfect joints of the FAHU, and any short-circuiting between primary and secondary airstreams are ignored.

\subsection{Ambient Conditions}

Figure 3 shows the ambient dry-bulb temperature and ambient relative humidity distribution measured at one-minute intervals, using a wireless data acquisition system, and recorded during the data collection period extending over several months. The dry-bulb temperature ranged from 23 to $44{ }^{\circ} \mathrm{C}$, while the relative humidity ranged from $10 \%$ to $69 \%$. The days when the ambient temperature was lower than $23^{\circ} \mathrm{C}$ are excluded from this study, as cooling is generally not required when temperatures are that low.

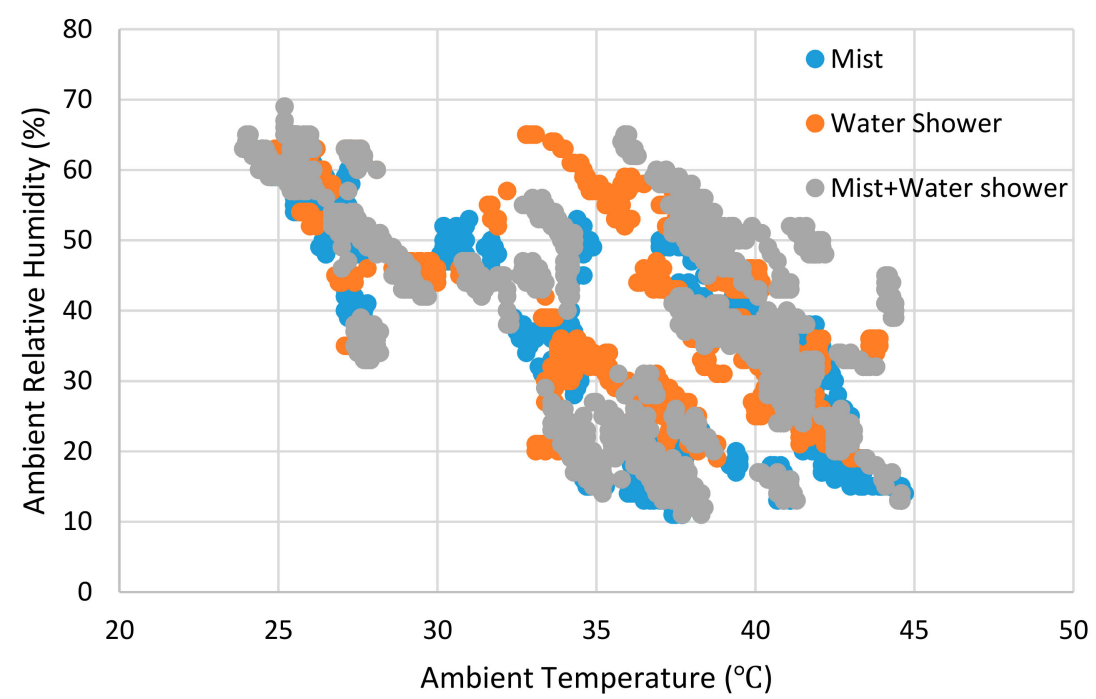

Figure 3. Distribution of ambient temperature and relative humidity during the data-collection period.

The measured ambient conditions are indicated for each mode of operation of the FAHU, purely to demonstrate and illustrate the overlap between conditions prevailing when the various modes of operation were implemented. The associated cooling performance parameters were measured at sensor locations (shown in Figure 1) within the FAHU. The overlap is necessary because it shows that comparisons between different modes of operation are on a like-to-like basis in terms of inlet ambient conditions. 


\subsection{Definition of Modes of Operation of the Fresh-Air-Handling Unit}

For this study, the following terminology is used to describe the different modes of operation:

(i) Single-effect DX only: mode of operation when the cooling of the primary airstream, from ambient condition to the desired supply air state, is achieved by using the direct expansion (DX) vapor compression cycle without engaging any evaporative cooling.

(ii) Dual-effect DX with mist injection: mode of operation when the primary airstream at ambient condition is pretreated by indirect evaporative cooling, using mist injection into the secondary airstream, before being further cooled to the desired supply air state, by the evaporator of the direct expansion (DX) cooling cycle.

(iii) Dual-effect DX with water shower: mode of operation when the primary airstream at ambient condition is pretreated by indirect evaporative cooling by a water shower cooling the wet channels of the crossflow heat exchanger, before being further cooled to the desired supply-air state by the evaporator of the direct expansion (DX) cooling cycle.

(iv) Triple-effect DX with mist injection and water shower: mode of operation when the secondary airstream cools the primary airstream by indirect evaporative cooling. The secondary airstream, ambient condition, is subjected to mist injection, which is followed by evaporative cooling, using a water shower in the wet channels of the crossflow heat exchanger. The primary airstream is then further cooled to the desired supply-air state, by the evaporator of the direct expansion (DX) cooling cycle.

The FAHU investigated can be used either as a full fresh-air system to provide cooling to a greenhouse for crop cultivation or as a fresh-air system serving outdoor or indoor spaces. In both cases, cooling is required when the ambient temperature and/or relative humidity exceeds the conditions required for the intended application. In greenhouses, the indoor microclimate is determined to meet the requirements of the crops to be cultivated, while for indoor human occupancy acceptable conditions are determined in accordance with the ASHRAE Standard 55 comfort zone, typically $20-24{ }^{\circ} \mathrm{C}$ and $30 \%-70 \% \mathrm{RH}$. The FAHU utilizes the above modes of operation to create desired conditions depending on the application.

\subsection{Cooling Performance Comparison Methodology}

To compare the cooling performance of various modes of operation, the data were downloaded from the server as Excel spreadsheets. Appropriate data from the different modes of operation were then identified by filtering based on either similar inlet ambient dry-bulb temperature (within a small range of about $1{ }^{\circ} \mathrm{C}$ or similar inlet ambient relative humidity (within a small range of $1 \%-3 \% \mathrm{RH}$ ). The use of small ranges of ambient dry-bulb and relative humidity was necessary to increase the number of datapoints. Corresponding parameters measured at sensor locations within the FAHU were then used in the analysis. Parameters at the exhaust from the FAHU were not controlled; hence, these were variable and different for each mode of operation. Firstly, the cooling performance of the FAHU and the behavior of the various modes of operation are considered for ambient conditions when the dry-bulb temperature is less than $40{ }^{\circ} \mathrm{C}$. The same aspects are considered at ambient dry-bulb temperatures higher than $40^{\circ} \mathrm{C}$, which was chosen as an arbitrary demarcation to represent extreme high ambient temperatures typical in the hot season of the local (Qatar) climate. Table 2 shows a schedule of cases analyzed for comparison of FAHU cooling performance in different modes. 
Table 2. Schedule of cases analyzed to be used for comparing different modes of operation.

\begin{tabular}{|c|c|c|c|c|c|}
\hline $\begin{array}{l}\text { Mode of } \\
\text { Operation }\end{array}$ & $\begin{array}{c}\text { Variation of } \\
\text { Temperature } \\
\text { Difference } \\
\text { across Heat } \\
\text { Exchanger } \\
\left(\Delta \mathrm{T}_{\mathrm{HX}}\right) \text { with } \\
\text { Changing } \\
\text { Ambient } \\
\text { Dry-Bulb } \\
\text { Temperature }\end{array}$ & $\begin{array}{c}\text { Variation of } \\
\text { Temperature } \\
\text { Difference } \\
\text { across Heat } \\
\text { Exchanger } \\
\left(\Delta \mathrm{T}_{\mathrm{HX}}\right) \text { with } \\
\text { Changing } \\
\text { Ambient } \\
\text { Relative } \\
\text { Humidity }\end{array}$ & $\begin{array}{c}\text { Variation of } \\
\text { Temperature } \\
\text { Difference } \\
\text { across DX } \\
\text { Cooling Coil } \\
\left(\Delta \mathrm{T}_{\mathrm{DX}}\right) \text { with } \\
\text { Changing } \\
\text { Ambient } \\
\text { Dry-Bulb } \\
\text { Temperature }\end{array}$ & $\begin{array}{c}\text { Variation of } \\
\text { Temperature } \\
\text { Difference } \\
\text { across Heat } \\
\text { Exchanger } \\
\left(\Delta \mathrm{T}_{\mathrm{DX}}\right) \text { with } \\
\text { Changing } \\
\text { Ambient } \\
\text { Relative } \\
\text { Humidity }\end{array}$ & $\begin{array}{c}\text { Electrical } \\
\text { Energy } \\
\text { Consumption } \\
\text { Associated } \\
\text { with Each } \\
\text { Mode of } \\
\text { Operation }\end{array}$ \\
\hline $\begin{array}{l}\text { Single-effect } \\
\text { DX only }\end{array}$ & $\mathrm{n} / \mathrm{a}$ & $\mathrm{n} / \mathrm{a}$ & $\begin{array}{l}\text { Figure } 6 \text { \& } \\
\text { (Figure 11) }\end{array}$ & $\begin{array}{l}\text { Figure } 7 \& \\
\text { (Figure 12) }\end{array}$ & $\begin{array}{l}\text { Figure } 8 \text { \& } \\
\text { (Figure 13) }\end{array}$ \\
\hline $\begin{array}{l}\text { Dual-effect } \\
\text { with mist } \\
\text { injection }\end{array}$ & $\begin{array}{c}\text { Figure } 5 \& \\
\text { (Figure 9) }\end{array}$ & $\begin{array}{l}\text { Figure } 4 \text { \& } \\
\text { (Figure 10) }\end{array}$ & $\begin{array}{l}\text { Figure } 6 \& \\
\text { (Figure 11) }\end{array}$ & $\begin{array}{l}\text { Figure } 7 \& \\
\text { (Figure 12) }\end{array}$ & $\begin{array}{l}\text { Figure } 8 \& \\
\text { (Figure 13) }\end{array}$ \\
\hline $\begin{array}{l}\text { Dual-effect } \\
\text { with water } \\
\text { shower }\end{array}$ & $\begin{array}{c}\text { Figure } 5 \& \\
\text { (Figure 9) }\end{array}$ & $\begin{array}{l}\text { Figure } 4 \text { \& } \\
\text { (Figure 10) }\end{array}$ & $\begin{array}{l}\text { Figure } 6 \& \\
\text { (Figure 11) }\end{array}$ & $\begin{array}{l}\text { Figure } 7 \& \\
\text { (Figure 12) }\end{array}$ & $\begin{array}{l}\text { Figure } 8 \text { \& } \\
\text { (Figure 13) }\end{array}$ \\
\hline $\begin{array}{c}\text { Triple-effect } \\
\text { with mist and } \\
\text { water shower }\end{array}$ & $\begin{array}{l}\text { Figure } 5 \text { \& } \\
\text { (Figure 9) }\end{array}$ & $\begin{array}{l}\text { Figure } 4 \& \\
\text { (Figure 10) }\end{array}$ & $\begin{array}{l}\text { Figure } 6 \text { \& } \\
\text { (Figure 11) }\end{array}$ & $\begin{array}{l}\text { Figure } 7 \& \\
\text { (Figure 12) }\end{array}$ & $\begin{array}{l}\text { Figure } 8 \text { \& } \\
\text { (Figure 13) }\end{array}$ \\
\hline
\end{tabular}

Note: Figure numbers shown in brackets relate to ambient dry-bulb temperatures $>40^{\circ} \mathrm{C}$.

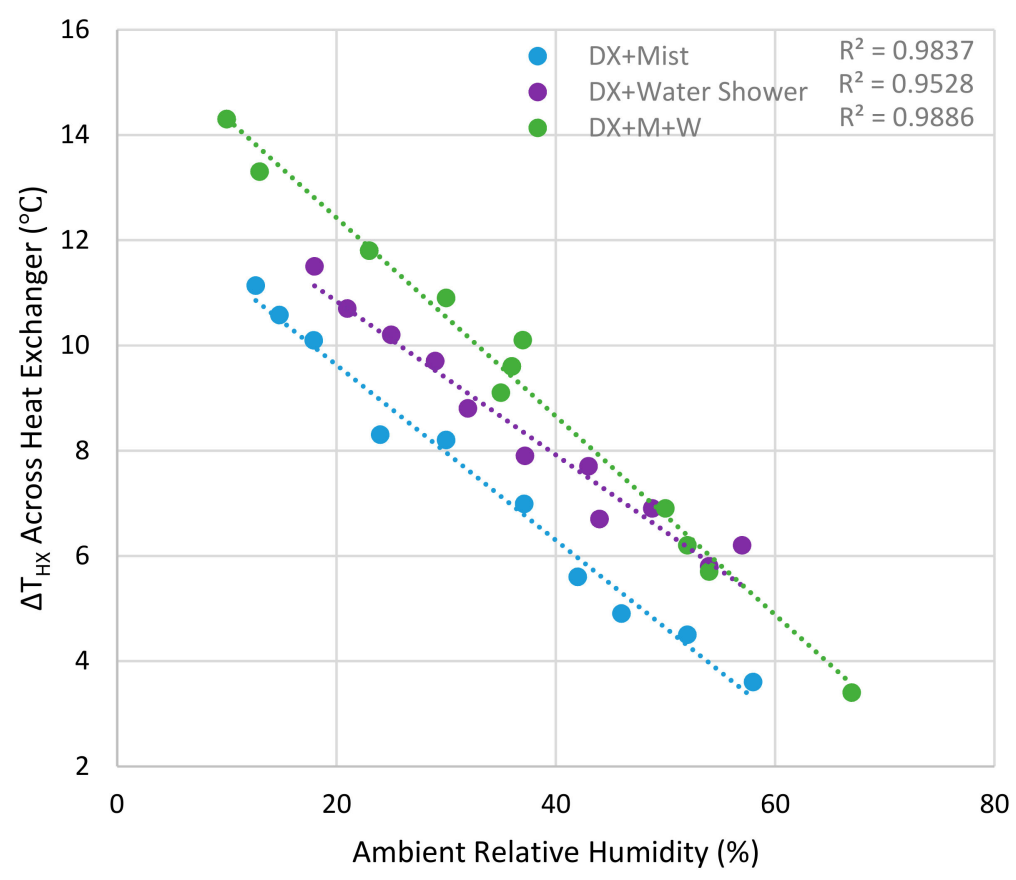

Figure 4. Variation of $\Delta \mathrm{T}_{\mathrm{HX}}$ with ambient relative humidity. 


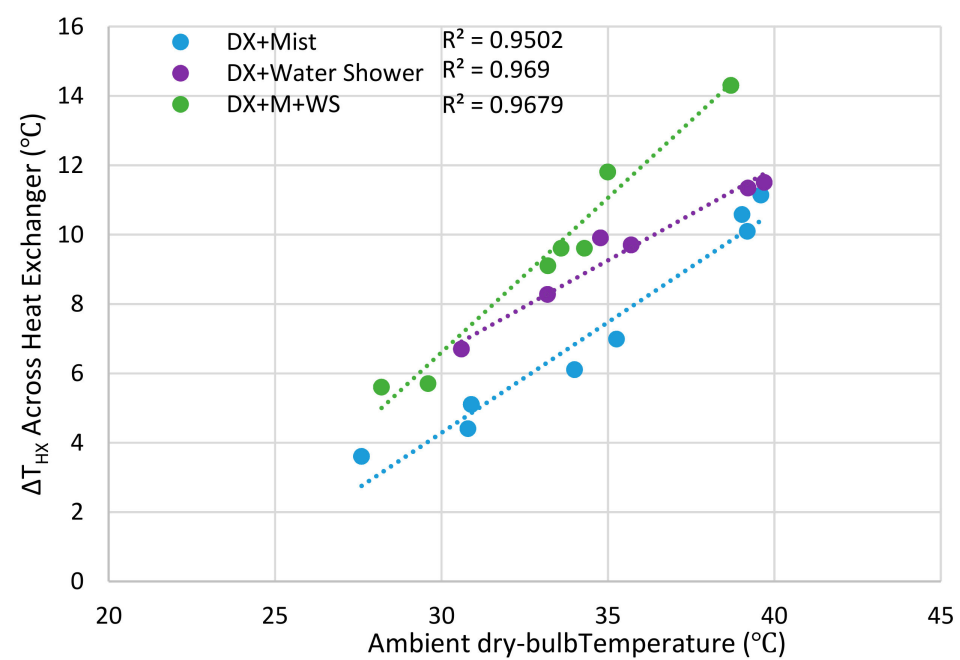

Figure 5. Variation of $\Delta \mathrm{T}_{H X}$ across indirect evaporative cooling (IEC) heat exchanger with dry-bulb temperature for ambient temperatures less than $40{ }^{\circ} \mathrm{C}$.

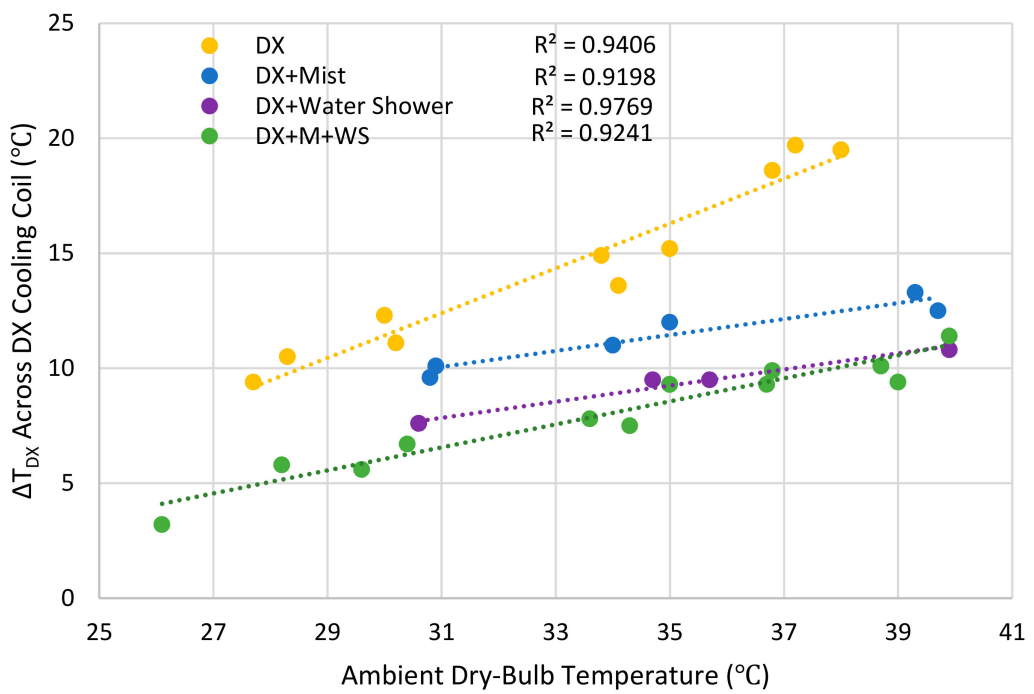

Figure 6. Temperature reduction of primary air across the direct expansion (DX) cooling coil for ambient dry-bulb temperature less than $40^{\circ} \mathrm{C}$.

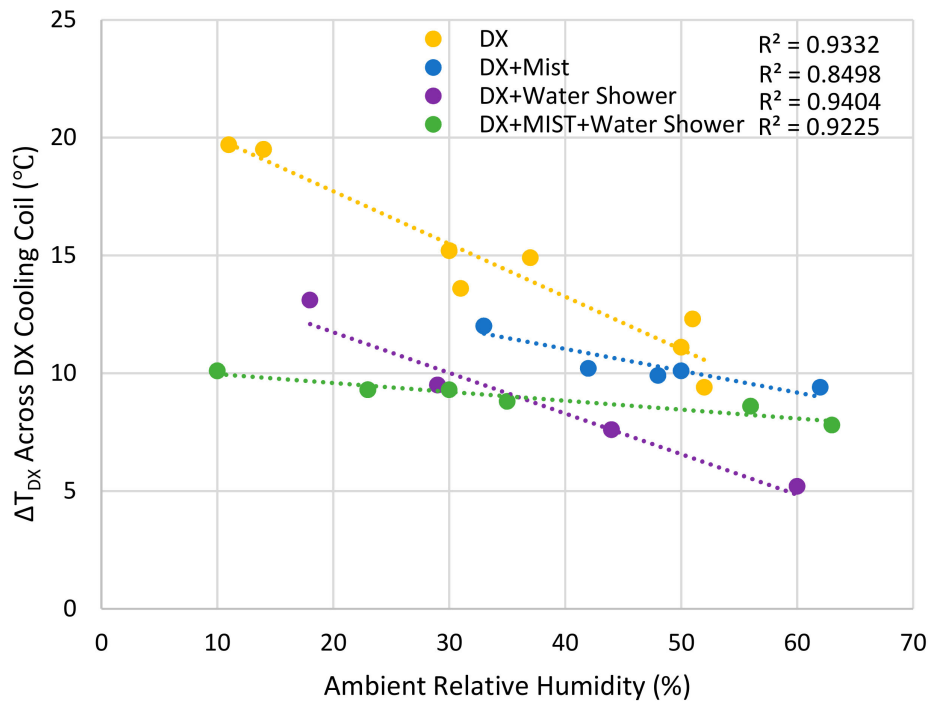

Figure 7. Variation of $\Delta \mathrm{T}_{\mathrm{DX}}$ with ambient relative humidity for ambient temperatures less than $40{ }^{\circ} \mathrm{C}$. 


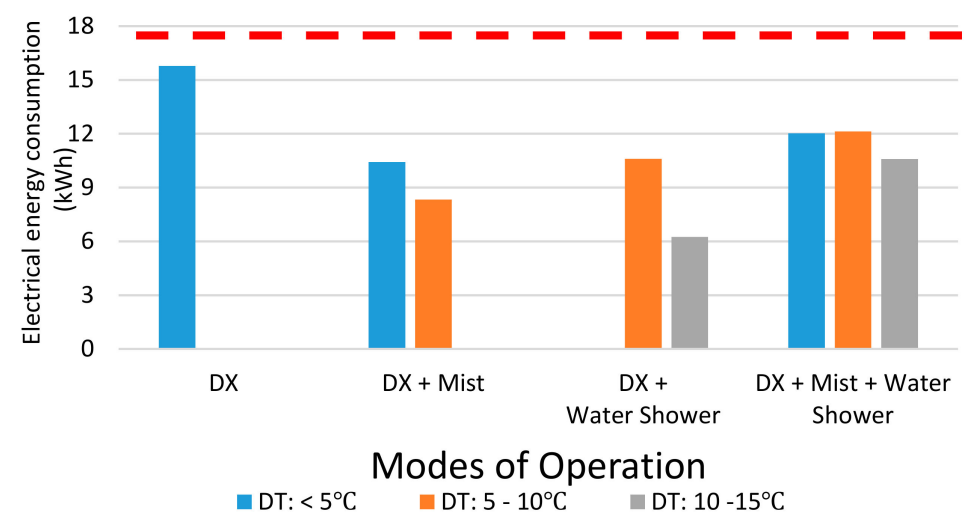

Figure 8. Electrical energy consumption of various modes of operation of the fresh-air-handling unit (FAHU) for different ranges of $\Delta \mathrm{T}_{\mathrm{HX}}$ in ambient temperatures less than $40{ }^{\circ} \mathrm{C}$.

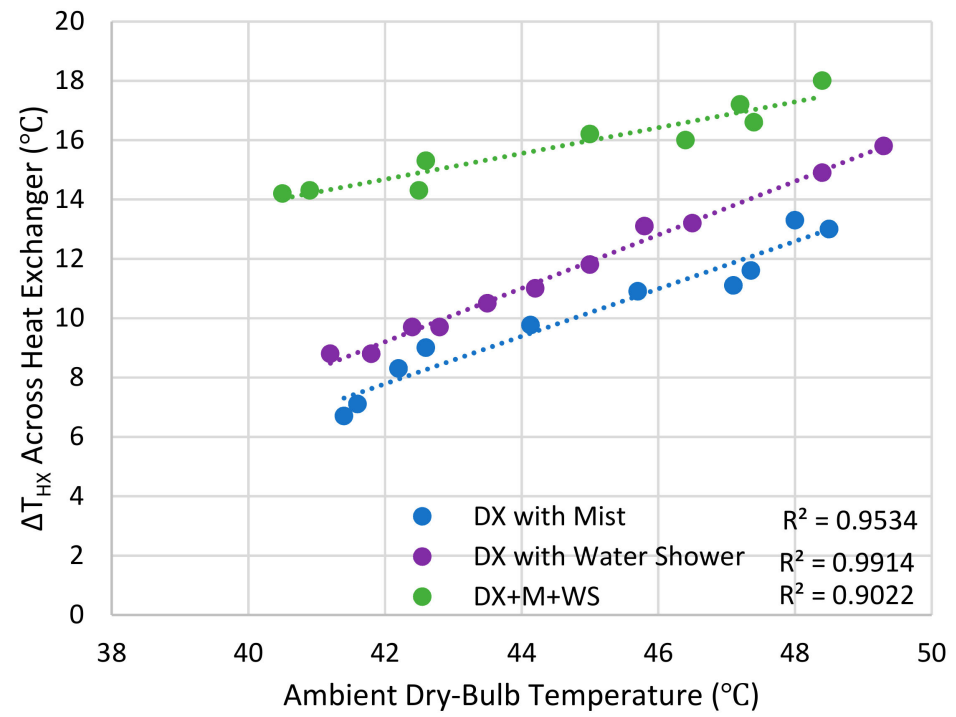

Figure 9. Variation with dry-bulb temperature of $\Delta \mathrm{T}_{\mathrm{HX}}$ across heat exchanger for ambient temperatures higher than $40{ }^{\circ} \mathrm{C}$.

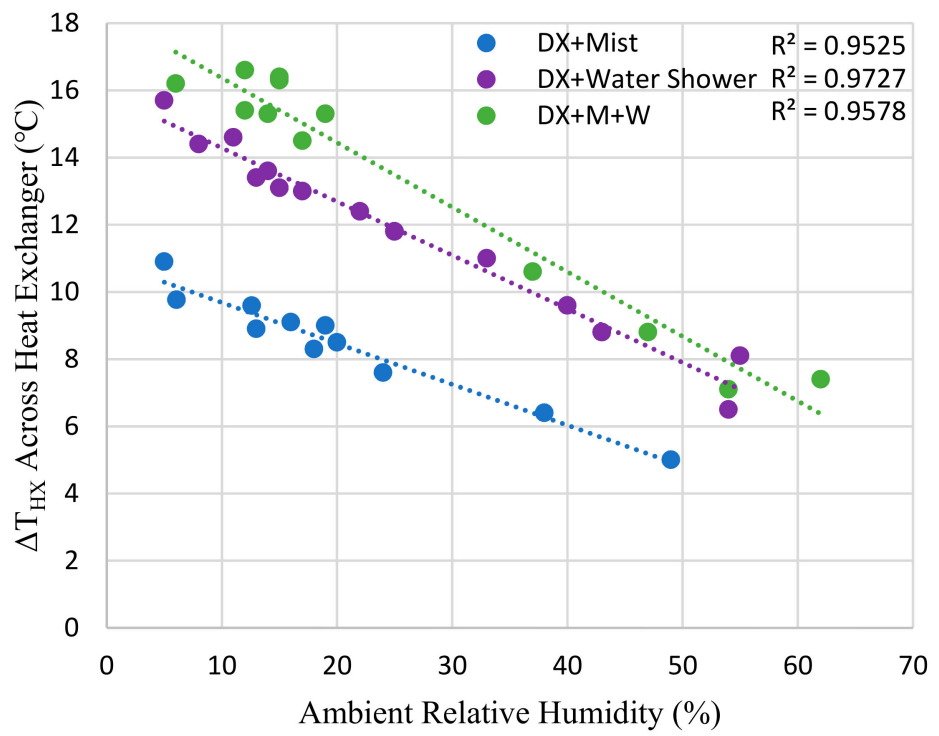

Figure 10. Variation with a relative humidity of $\Delta \mathrm{T}_{\mathrm{HX}}$ across heat exchanger for ambient temperatures higher than $40{ }^{\circ} \mathrm{C}$. 


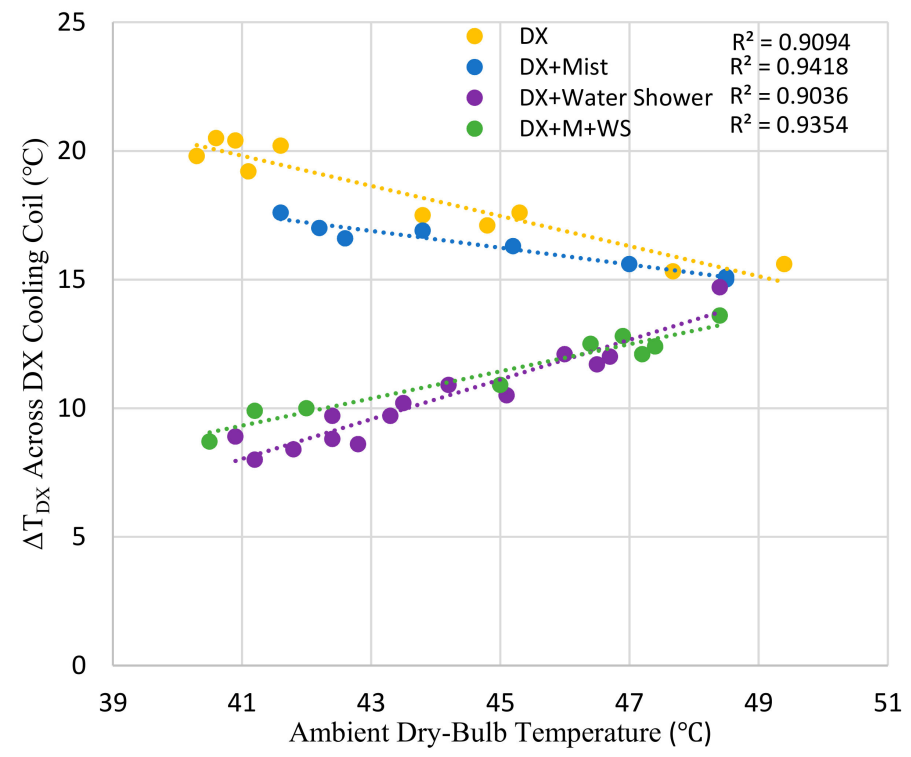

Figure 11. Variation of $\Delta \mathrm{T}_{\mathrm{DX}}$ across the DX cooling coil with dry-bulb temperature for ambient temperatures higher than $40{ }^{\circ} \mathrm{C}$.

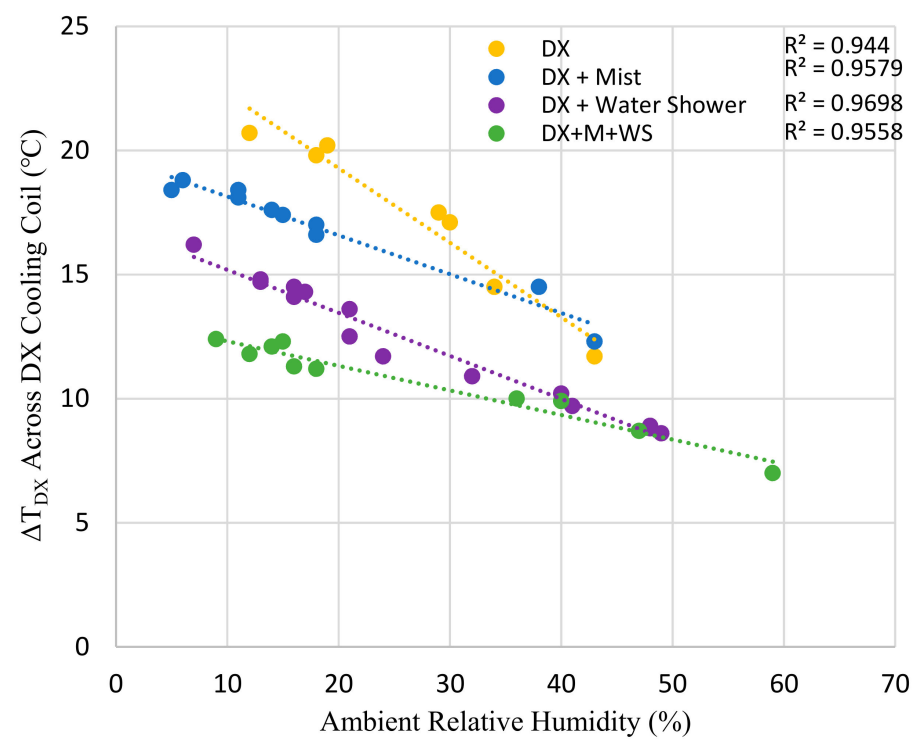

Figure 12. Variation of $\Delta \mathrm{T}_{\mathrm{DX}}$ across the $\mathrm{DX}$ cooling coil with relative humidity for ambient temperatures higher than $40^{\circ} \mathrm{C}$.

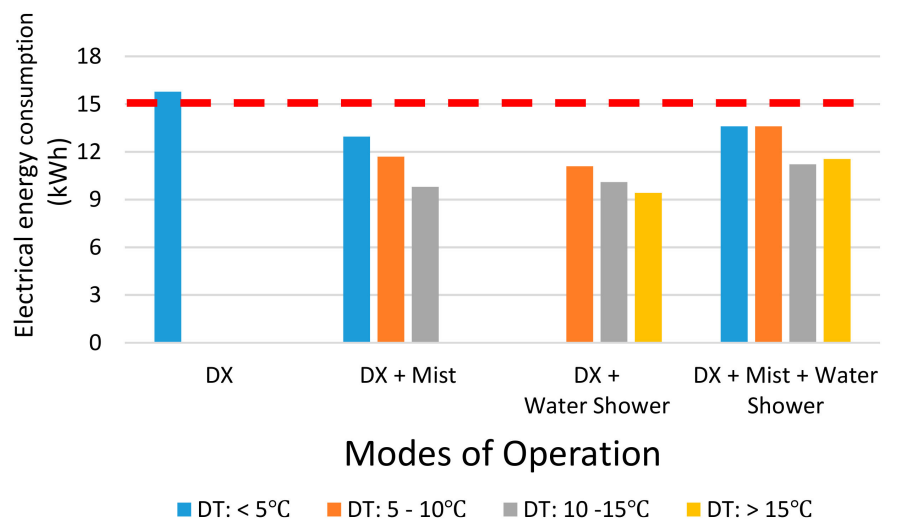

Figure 13. Electrical energy consumption of various modes of operation of the FAHU for different ranges of $\Delta \mathrm{T}_{\mathrm{HX}}$ in ambient temperatures higher than $40{ }^{\circ} \mathrm{C}$. 
At given ambient conditions, the temperature difference across the heat exchanger was calculated as the difference between the dry-bulb temperature at the inlet to the crossflow heat exchanger, and the dry-bulb temperature at the outlet from the heat exchanger (Equation (1)).

$$
\Delta \mathrm{T}_{\mathrm{HX}}=\mathrm{T}_{2}-\mathrm{T}_{3}
$$

Similarly, the temperature difference across the DX cooling coil was calculated as the difference between the dry-bulb temperature at the inlet to the DX cooling coil, and the dry-bulb temperature at the outlet from the DX cooling coil (Equation (2)).

$$
\Delta \mathrm{T}_{\mathrm{DX}}=\mathrm{T}_{3}-\mathrm{T}_{4}
$$

The electrical energy consumption of each mode of operation, under given ambient conditions, was measured with an energy meter installed within the electrical circuitry of the FAHU. Electrical energy consumptions of the various modes of operation were based on one-hour operation of each mode. When operating in the single-effect DX-only mode, the FAHU consumes energy used by the supply air fan, exhaust air fan, and the DX compressors. For the dual and triple-effect modes, additional power is consumed by the ultrasonic mist generator and water pump as required for the engaged mode of operation. The humidifier downstream of the supply-air fan was not used in the investigations; hence, its electrical energy consumption is not included in this study.

The coefficient of performance (COP) of the FAHU can be calculated as the ratio of the cooling capacity to the electrical energy consumed, as follows:

$$
\mathrm{COP}=\frac{\mathrm{Q}_{\mathrm{e}}}{\mathrm{W}_{\mathrm{c}}}
$$

\section{Results and Discussion}

The results obtained from the experimental data analysis are presented and discussed in this section.

The results are first considered from the angle of temperature reduction $\left(\Delta \mathrm{T}_{\mathrm{HX}}\right)$, of the primary airstream, across the indirect evaporative cooling heat exchanger, as an indicator of the cooling performance of the FAHU. The study examines the behavior of $\Delta \mathrm{T}_{\mathrm{HX}}$ with the ambient dry-bulb temperature, as well as the ambient relative humidity. This assessment is essential, in order to understand the contribution of the IEC effect to the reduction of cooling demand required to condition the primary airstream from ambient condition to the desired supply-air state.

Similarly, the behavior of the temperature reduction of the primary airstream flowing across the evaporator the DX cooling cycle $\left(\Delta \mathrm{T}_{\mathrm{DX}}\right)$, and its variation with the ambient dry-bulb temperature and ambient relative humidity are explored for each mode of operation of the FAHU.

Secondly, the electrical energy consumption of the various modes of operation is compared, to quantify the benefit or contribution of IEC, using mist injection and the water shower to supplement the cooling demand required to condition ambient primary air to the desired supply-air state. The electrical energy consumption thus indicates the cooling performance of the FAHU, whereby a lower electrical energy consumption translates to better cooling performance.

For this study, cooling performance is assessed from two main perspectives. Firstly, the contributions resulting from temperature reduction of the primary airflow across the indirect evaporative cooling heat exchanger in combination with cooling provided by the evaporator of the DX cooling cycle. Secondly, from the angle of the power consumed by the FAHU as it cools the primary airstream from ambient condition to the desired supply-air state. It is worth noting that the main components that consume energy within the FAHU are evaporative cooling water pumps, ultrasonic mist generators, ventilation fans for the primary and secondary airstreams, and the power consumed for refrigeration by vapor compression DX cooling cycle. 


\subsection{Cooling Performance of FAHU in Ambient Dry-Bulb Temperatures Less than $40^{\circ} \mathrm{C}$}

Results obtained from the experimental data analysis of the cooling performance of the FAHU, in ambient dry-bulb temperatures less than $40^{\circ} \mathrm{C}$, are presented and discussed in the following sections.

3.1.1. Experimentally Measured Temperature Reduction across the IEC Crossflow Heat Exchanger $\left(\Delta \mathrm{T}_{\mathrm{HX}}\right)$ for Ambient Dry-by-Bulb Temperatures Less than $40^{\circ} \mathrm{C}$

The variations of temperature reduction, because of indirect evaporative cooling across the heat exchanger $\left(\Delta \mathrm{T}_{\mathrm{HX}}\right)$, as a function of ambient relative humidity, as shown in Figure 4 , are represented by linear functions of which excellent correlation coefficients greater than 0.933 were obtained for all modes of operation of the FAHU.

All three modes of operation present a decreasing trend of $\Delta \mathrm{T}_{\mathrm{HX}}$ with increasing ambient relative humidity. As the relative humidity increases, the latent cooling effect of the secondary air decreases because the air becomes more saturated, reducing the capacity of cooling of the primary air by the secondary air.

For the recorded range of experimental measurements, temperature reductions across the IEC heat exchanger as a function of ambient relative humidity range from 3.4 to $14.3^{\circ} \mathrm{C}$. Across the range of relative humidity measured during the experiments, the triple-effect 'DX with mist and water shower' mode of operation gives higher values of $\Delta \mathrm{T}_{\mathrm{HX}}$ than the other modes of operation. On the contrary, the dual-effect 'DX with mist injection' achieves the lowest values of $\Delta \mathrm{T}_{\mathrm{HX}}$ for corresponding at corresponding ambient relative humidity. The trend of values of $\Delta \mathrm{T}_{\mathrm{HX}}$ achieved by dual-effect 'DX with water shower' mode of operation falls between those achieved by the triple-effect 'DX with mist and water shower' and the dual-effect 'DX with mist injection' modes of operation of the FAHU. Figure 4 also reveals that the difference in values of $\Delta \mathrm{T}_{\mathrm{HX}}$ achieved by the triple-effect mode and the dual-effect 'DX with water shower' progressively decreases with increasing relative humidity. The lines representing the $\Delta \mathrm{T}_{\mathrm{HX}}$ trends of these modes of operation cross at an ambient relative humidity of $60 \%$ $\mathrm{RH}$, beyond which the dual-effect 'DX with water shower' mode achieves better values of $\Delta \mathrm{T}_{\mathrm{HX}}$ than the triple-effect mode.

Also considered was the variation of temperature reduction, because of indirect evaporative cooling across the heat exchanger $\left(\Delta \mathrm{T}_{\mathrm{HX}}\right)$, as a function of ambient dry-bulb temperature. These were compared for various modes of operation, as shown in Figure 5. A linear representation of the behavior of $\Delta \mathrm{T}_{\mathrm{HX}}$ as a function of ambient dry-bulb temperature gave excellent correlation coefficients greater than 0.962 for all modes of operation of the FAHU. As the ambient temperature increases, the difference between the dry-bulb temperature $\left(\mathrm{T}_{\mathrm{db}}\right)$ and the wet-bulb temperature $\left(\mathrm{T}_{\mathrm{wb}}\right)$ also increases. The higher the difference between $T_{d b}$ and $T_{w b}$, the greater is the potential of the primary airstream to be cooled, which is the reason why Figure 5 shows increasing trends of the various modes of operation.

The use of mist injection in combination with the water shower achieves the highest reduction of temperature as it flows across the IEC heat exchanger. For the experimental range considered the highest $\Delta \mathrm{T}_{\mathrm{HX}}$ achieved by the FAHU, when viewed as a variation of ambient temperature, is $14.3^{\circ} \mathrm{C}$. The use of mist injection only achieves the lowest values of $\Delta \mathrm{T}_{\mathrm{HX}}$ for corresponding at corresponding ambient dry-bulb temperatures, whereby the lowest $\Delta \mathrm{T}_{\mathrm{HX}}$ achieved is $3.6^{\circ} \mathrm{C}$. The trend of values of $\Delta \mathrm{T}_{\mathrm{HX}}$ achieved with the use of the water shower falls between those achieved by the combined use of mist with a water shower, and that of the mist injection. Figure 5 reveals that at a dry-bulb temperature of approximately $30^{\circ} \mathrm{C}$, the combined use of mist and water shower achieves the same $\Delta \mathrm{T}_{\mathrm{HX}}$ as the use of water shower only, i.e., $6.5^{\circ} \mathrm{C}$. For ambient temperatures higher than $30^{\circ} \mathrm{C}$, the difference in $\Delta \mathrm{T}_{\mathrm{HX}}$ between the mist with water shower trend and that of the water shower progressively increases. On the other hand, the difference in $\Delta \mathrm{T}_{\mathrm{HX}}$ between the water shower trend and that of the mist injection decreases with increasing ambient dry-bulb temperature. 
3.1.2. Experimentally Measured Temperature Reduction across DX Cooling Coil $\left(\Delta \mathrm{T}_{\mathrm{DX}}\right)$ for Ambient Dry-by-Bulb Temperatures Less than $40^{\circ} \mathrm{C}$

The results of the variation of reduction of the temperature of the primary airstream flowing across the evaporator of the refrigeration cycle, DX cooling coil, for different modes of operation are shown in Figure 6. For all modes of operation, the system performance improves as the ambient dry-bulb temperature rises. Based on the excellent correlation coefficients obtained from the experiment data, it is reasonable that the temperature reduction of the air flowing across the DX cooling coil $\left(\Delta \mathrm{T}_{\mathrm{DX}}\right)$, as a function of the ambient dry-bulb temperature is represented by linear relationship for all modes of operation of the FAHU.

The use of the indirect evaporative cooling modes reduces the amount of cooling handled by the DX cooling coil because the IEC provides the initial temperature reduction i.e., sensible cooling of the primary airstream across the heat exchanger.

It can be seen from Figure 6 that temperature reduction dealt with by only the single-effect DX mode of operation increases from $10^{\circ} \mathrm{C}$ at the ambient dry-bulb temperature of $28^{\circ} \mathrm{C}$, to $19.5^{\circ} \mathrm{C}$ when the ambient temperature reaches $38^{\circ} \mathrm{C}$. For the range of ambient dry-bulb temperatures measured, the most considerable cooling effect on the DX cooling coil equates to approximately $20^{\circ} \mathrm{C}$, while the least cooling effect, of $4.2^{\circ} \mathrm{C}$, occurs with the triple-effect ' $\mathrm{DX}$ with mist and water shower' mode of operation. At the limiting boundary of the ambient dry-bulb temperature $\left(40^{\circ} \mathrm{C}\right)$, the dual-effect 'DX with water shower' experiences the same cooling demand across the DX cooling coil as that required by the triple-effect mode of operation. Similarly, at an ambient dry-bulb temperature of $27.5^{\circ} \mathrm{C}$, the dual-effect ' $\mathrm{DX}$ with mist' mode of operation requires the same effort to cool the primary or supply airstream flowing across the DX cooling coil. The difference in cooling effort between the single-effect DX-only mode of operation and the wet modes progressively increases with increasing ambient dry-bulb temperature.

The variation of the cooling demand or effort required by the various modes of operation, represented as a reduction in temperature $\Delta \mathrm{T}_{\mathrm{DX}}$ of the primary/supply airstream flowing across the evaporator (DX cooling coil), as a function of ambient relative humidity, is also considered. The results presented in Figure 7 show that linear representation of the behavior of $\Delta \mathrm{T}_{\mathrm{Dx}}$ gives excellent correlation coefficients, exceeding 0.922 in all cases, except the double-effect 'DX with mist' mode of operation.

Concerning the ambient relative humidity, the temperature reduction of the primary/supply airstream that the DX-only operating mode is expected to deal with decreases from $19.5^{\circ} \mathrm{C}$ at $11 \% \mathrm{RH}$ to $10^{\circ} \mathrm{C}$ at approximately $55 \% \mathrm{RH}$. As the ambient relative humidity increases up to about $35 \% \mathrm{RH}$, it is found that using the combination of mist and water shower across the IEC heat exchanger requires the least amount of cooling demand or cooling effort across the DX cooling coil. Above $35 \% \mathrm{RH}$, the dual-effect 'DX with water shower' requires the lowest amount of cooling effort. At approximately $55 \% \mathrm{RH}$, the single-effect 'DX only' and the dual-effect 'DX with mist' modes of operation require the same amount of cooling effort across the DX cooling coil to achieve the desired supply-air state.

For FAHU investigated, it appears as though the dual-effect 'DX with mist' and the triple-effect 'DX with mist and water shower' modes of operation would encounter the same cooling demand somewhere at ambient relative humidity higher than $65 \% \mathrm{RH}$. On the other hand, there is little distinction between the dual-effect 'DX with mist' and dual-effect 'DX with water shower' modes of operation requires at low ambient relative humidity. These two modes of operation require the same amount of cooling effort across the DX cooling coil, to achieve the desired supply air state, at an ambient relative humidity of $10 \% \mathrm{RH}$, for the FAHU used in this study.

3.1.3. Experimentally Measured Power Consumed by Different Modes of Operation of the FAHU for Ambient Dry-by-Bulb Temperatures Less than $40^{\circ} \mathrm{C}$

The cooling performance of the various modes of operation of the FAHU is also considered in terms of electrical energy consumption. The desired supply-air condition to be used in the analysis is determined by averaging the temperature and relative humidity measured for all modes of operation, 
immediately downstream of the DX cooling coil. The averaged values resulted in a supply-air state of $16^{\circ} \mathrm{C}$ and $90 \% \mathrm{RH}$. The variation of electrical energy consumption for several ranges of $\Delta \mathrm{T}_{\mathrm{HX}}$ i.e., $\left(\Delta \mathrm{T}_{\mathrm{HX}}<5^{\circ} \mathrm{C} ; 5^{\circ} \mathrm{C}<\Delta \mathrm{T}_{\mathrm{HX}} \leq 10^{\circ} \mathrm{C} ; 10^{\circ} \mathrm{C}<\Delta \mathrm{T}_{\mathrm{HX}} \leq 15^{\circ} \mathrm{C}\right.$; and $\left.\Delta \mathrm{T}_{\mathrm{HX}}>15^{\circ} \mathrm{C}\right)$ is presented in Figure 8 .

The single-effect ' $\mathrm{DX}$ only' cooling mode has the highest cooling demand with an electrical energy consumption of $15.78 \mathrm{kWh}$, while the lowest cooling demand, of $6.24 \mathrm{kWh}$, occurs with the dual-effect 'DX with water shower' mode when the contribution of the IEC is between 10 and $15{ }^{\circ} \mathrm{C}$ across the crossflow heat exchanger.

For ambient temperatures lower than $40^{\circ} \mathrm{C}$, it is evident from Figure 8 that, with mist injection, the FAHU did not achieve temperature reductions higher than $10^{\circ} \mathrm{C}$, across the IEC heat exchanger. Also, the results show that for the experimental range considered, the water shower provides a cooling contribution higher than $5{ }^{\circ} \mathrm{C}$ in terms of reduction of the temperature of the primary airstream flowing through the IEC heat exchanger. As expected, the electrical energy consumption of the FAHU reduces when the cooling contribution of the IEC heat exchanger increases. However, there appears to be a marginal increase in electrical energy consumption of the triple-effect mode of operation when the cooling contribution, $\Delta \mathrm{T}_{\mathrm{HX}}$, changes from the less than $5^{\circ} \mathrm{C}$ range to $5-10^{\circ} \mathrm{C}$. The increase in power could be attributed to a surge in electrical energy consumption when the three effects are engaged together, and/or a slight difference in the total cooling load imposed on the FAHU.

By looking at the range of $\Delta \mathrm{T}_{\mathrm{HX}}$ less than $5^{\circ} \mathrm{C}$, it is seen that the triple-effect mode of operation consumes $15.3 \%$ more energy, to achieve the target supply-air state $\left(16^{\circ} \mathrm{C}\right.$ and $\left.90 \% \mathrm{RH}\right)$, than does the dual-effect 'DX with mist' mode. The single-effect 'DX only' mode of operation consumes $51.4 \%$ more energy than the dual-effect 'DX with mist' mode of operation.

For the $\Delta \mathrm{T}_{\mathrm{HX}}: 5-10{ }^{\circ} \mathrm{C}$ range of temperature reduction, it is found that the triple-effect ' $\mathrm{DX}$ with mist and water shower' mode of operation consumes $45.6 \%$ and $14.4 \%$ more energy than the dual-effect 'DX with mist' and dual-effect 'DX with water shower' modes of operation, respectively. However, when the best-performing mode of operation (i.e., dual-effect 'DX with water shower') saves $60.4 \%$ of the energy required by the single-effect 'DX only' mode of operation.

The coefficient of performance (COP) of the FAHU when operating in ambient dry-bulb temperatures less than $40{ }^{\circ} \mathrm{C}$ are calculated for an arbitrary average ambient condition of $39{ }^{\circ} \mathrm{C}$ and $13.4 \% \mathrm{RH}$. The average ambient condition is selected by inspection of the available experimentally measured data. The results of the calculated COPs are presented in Table 3.

Table 3. COP calculated from experimental data for ambient temperatures less than $40^{\circ} \mathrm{C}$.

\begin{tabular}{cc}
\hline Mode of Operation & Coefficient of Performance (COP) \\
\hline DX & 2.49 \\
IEC (mist with water shower) & 0.92 \\
Combined DX + IEC & 4.99 \\
\hline
\end{tabular}

It is found that the use IEC in combination with DX cooling doubles the COP of the FAHU. The improvement in performance is due to the reduction in electrical energy consumption associated with the contribution of the sensible cooling provided by the IEC heat exchanger.

\subsection{Cooling Performance of FAHU in Ambient Dry-Bulb Temperatures Greater than $40^{\circ} \mathrm{C}$}

In the following sections, the results relating to the cooling performance of the FAHU and the behavior of the different modes of operation are presented and discussed. As indicated on the graphs in this section, excellent correlation coefficients were obtained for the linear representation of the trends for the various modes of operation. 
3.2.1. Experimentally Measured Temperature Reduction across the IEC Crossflow Heat Exchanger $\left(\Delta \mathrm{T}_{\mathrm{HX}}\right)$ for Ambient Dry by Bulb Temperatures Higher than $40^{\circ} \mathrm{C}$

The variation, with dry-bulb temperature, of the temperature reduction across the IEC heat exchanger for ambient temperatures higher than $40{ }^{\circ} \mathrm{C}$ is shown in Figure 9. It is found that the triple-effect 'DX with mist and water shower' mode of operation achieves the highest $\Delta \mathrm{T}_{\mathrm{HX}}$ over the range of temperatures measured. The highest $\Delta \mathrm{T}_{\mathrm{HX}}$ achieved using both mist injection and water shower is $18{ }^{\circ} \mathrm{C}$, while the lowest achieved by this mode of operation is $14.2{ }^{\circ} \mathrm{C}$. This result is followed by the dual-effect 'DX with water shower' mode for which the highest $\Delta \mathrm{T}_{\mathrm{HX}}$ is $15.8^{\circ} \mathrm{C}$, and the lowest is $8.8^{\circ} \mathrm{C}$, and the dual-effect ' $\mathrm{DX}$ with mist' achieves the smallest temperature differences across the heat exchanger in ambient conditions of ambient temperatures higher than $40^{\circ} \mathrm{C}$. Its minimum and maximum $\Delta \mathrm{T}_{\mathrm{HX}}$ are 6.7 and $13.0^{\circ} \mathrm{C}$, respectively.

While the difference in $\Delta \mathrm{T}_{\mathrm{HX}}$ between the dual-effect modes of operation is nearly constant (a difference of about $2{ }^{\circ} \mathrm{C}$, though in the fact it increases only marginally) over the range of the experimental measurements, that between the triple-effect 'DX with mist and water shower' and the dual-effect modes of operation decreases with increasing ambient dry-bulb temperature. In the same way as the behavior in ambient conditions of dry-bulb temperatures less than $40{ }^{\circ} \mathrm{C}$, the combination of mist injection and water shower provides the highest temperature reductions across the IEC heat exchanger. Of the three modes of operation, the use of mist injection provides the lowest temperature reductions across the heat exchanger.

The behavior of the temperature reductions of the primary airstream flowing across the heat exchanger as a function of relative humidity for ambient temperatures higher than $40{ }^{\circ} \mathrm{C}$ is shown in Figure 10. The trends for all modes of operation depict a reducing behavior, whereby the differences in $\Delta \mathrm{T}_{\mathrm{HX}}$ of the different modes are progressively reduced as relative humidity increases.

Compared to the trends of the corresponding behavior, at ambient temperatures lower than $40{ }^{\circ} \mathrm{C}$, of the various modes of operation, the gap between $\Delta \mathrm{T}_{\mathrm{HX}}$ of the dual-effect modes is much more comprehensive for ambient temperatures higher than $40^{\circ} \mathrm{C}$. However, that between the triple-effect 'DX with mist water shower' and the dual-effect 'DX with mist' modes of operation remains identical. Also, in general, the various modes of operation achieve higher $\Delta \mathrm{T}_{\mathrm{HX}}$ for ambient temperatures above $40{ }^{\circ} \mathrm{C}$, than when ambient temperatures are below $40^{\circ} \mathrm{C}$.

The difference in $\Delta \mathrm{T}_{\mathrm{HX}}$ between the best-performing mode (triple effect) and the least (dual-effect 'DX with mist) decreases with increasing relative humidity. At $10 \% \mathrm{RH}$, the difference in $\Delta \mathrm{T}_{\mathrm{HX}}$ is $6.7^{\circ} \mathrm{C}$, and at $50 \% \mathrm{RH}$, the gap decreases to $4.5^{\circ} \mathrm{C}$.

\subsubsection{Experimentally Measured Temperature Reduction across Cooling Coil $\left(\Delta \mathrm{T}_{\mathrm{DX}}\right)$ for Ambient} Dry-by-Bulb Temperatures Higher than $40{ }^{\circ} \mathrm{C}$

The variation of $\Delta \mathrm{T}_{\mathrm{Dx}}$ with ambient dry-bulb temperature is shown in Figure 11. The triple-effect 'DX with mist and water shower' and the dual-effect 'DX with water shower' have an increasing trend, with increasing ambient dry-bulb temperature, like the behavior seen for dry-bulb temperatures less than $40{ }^{\circ} \mathrm{C}$. However, for ambient dry-bulb temperatures above $40^{\circ} \mathrm{C}$, the trends of $\Delta \mathrm{T}_{\mathrm{HX}}$ for the single-effect 'DX only' and the dual-effect 'DX with mist' decreases with increasing ambient dry-bulb temperature, unlike the corresponding trends for these two modes of operation in ambient dry-bulb temperatures less than $40^{\circ} \mathrm{C}$ (see Figure 5).

For the experimental range considered in this study, it is seen that for ambient dry-bulb temperatures lower than approximately $46^{\circ} \mathrm{C}$, the dual-effect 'DX with mist' mode of operation requires the lowest cooling effort across the DX cooling coil. However, for ambient dry-bulb temperatures greater than $46^{\circ} \mathrm{C}$, the triple-effect ' $\mathrm{DX}$ with mist and water shower' requires the lowest cooling effort across the FAHU's DX cooling coil. Also, it is found that the highest cooling demand on the DX cooling coil is $20.5^{\circ} \mathrm{C}$. Only the single-effect 'DX only' mode of operation would be able to meet this cooling demand, at an ambient dry-bulb temperature of $40.6^{\circ} \mathrm{C}$. 
The lowest measured cooling demand of $7.5 \mathrm{kWh}$ occurs for the dual-effect 'DX with water shower' at an ambient dry-bulb temperature of approximately $41^{\circ} \mathrm{C}$. Further, it is seen than the difference between the trends of the highest and lowest cooling effort required across the DX cooling coil, progressively decreases with increasing ambient dry-bulb temperature. For the range of experimental results, the most significant difference between the single-effect 'DX only' mode and the dual-effect 'DX with water shower' is almost $12.5^{\circ} \mathrm{C}$, which gradually decreases to approximately $2.5^{\circ} \mathrm{C}$ as the dry-bulb temperature reaches $48.5^{\circ} \mathrm{C}$.

Interestingly, the behavior of $\Delta \mathrm{T}_{\mathrm{DX}}$ as a function of ambient relative humidity, in conditions of dry-bulb temperature higher than $40{ }^{\circ} \mathrm{C}$, as seen in Figure 12, shows decreasing trends as ambient relative humidity increases for all modes of operation of the FAHU.

Figure 12 reveals that for the experimental range of parameters, the triple-effect ' $\mathrm{DX}$ with mist and water shower' has the lowest cooling demand, which is of approximately $7^{\circ} \mathrm{C}$, across the DX cooling coil, at an ambient relative humidity of $59 \% \mathrm{RH}$. The cooling demand across the DX cooling increases to $12{ }^{\circ} \mathrm{C}$ when the ambient relative humidity reduces to $10 \% \mathrm{RH}$. As expected, the single-effect ' $\mathrm{DX}$ only' has the highest cooling demand across the DX cooling coil, equating to approximately $22{ }^{\circ} \mathrm{C}$ at an ambient relative humidity of $10 \% \mathrm{RH}$. The cooling imposed on the DX cooling coil reduces by about half $\left(11^{\circ} \mathrm{C}\right)$ when the ambient relative humidity increases from $10 \%$ to $40 \% \mathrm{RH}$. The results are shown in Figure 12 and also suggest that the dual-effect 'DX with mist' has the same cooling requirement (equating to $13^{\circ} \mathrm{C}$ ) on the DX cooling coil as the single-effect 'DX only' mode when ambient relative humidity increases to $39 \% \mathrm{RH}$. The difference between the $\Delta \mathrm{T}_{\mathrm{DX}}$ trends of the single-effect ' $\mathrm{DX}$ only' mode and the wet modes of operation all reduce with increasing ambient relative humidity. Also, it is found that the difference in $\Delta \mathrm{T}_{\mathrm{DX}}$ of the dual-effect modes of operation remains nearly constant over the range of experimental measurements. Between these two modes of operation, the dual-effect ' $D X$ with water shower' encounters a lower cooling demand on the DX cooling coil than the dual-effect 'DX with mist.' The reduction in demand means that the water shower achieves more-significant temperature reductions across the IEC heat exchanger than does the mist injection for similar levels of ambient relative humidity.

3.2.3. Experimentally Measured Power Consumed by Different Modes of Operation of the FAHU for Ambient Dry-by-Bulb Temperatures Higher than $40^{\circ} \mathrm{C}$

The results of the experimentally measured energy consumed by various modes of operation of the FAHU for ambient dry-bulb temperatures greater than $40^{\circ} \mathrm{C}$ are shown in Figure 13. For these conditions, the same supply-air state $\left(16^{\circ} \mathrm{C}\right.$ and $\left.90 \% \mathrm{RH}\right)$ is set as the desired supply-air condition, and the power required by each mode of operation was recorded during the experimental measurements.

As before, a few temperature ranges of $\Delta \mathrm{T}_{\mathrm{HX}}\left(\Delta \mathrm{T}_{\mathrm{HX}}<5{ }^{\circ} \mathrm{C} ; 5^{\circ} \mathrm{C}<\Delta \mathrm{T}_{\mathrm{HX}} \leq 10^{\circ} \mathrm{C} ; 10^{\circ} \mathrm{C}<\Delta \mathrm{T}_{\mathrm{HX}}\right.$ $\leq 15^{\circ} \mathrm{C}$; and $\Delta \mathrm{T}_{\mathrm{HX}}>15^{\circ} \mathrm{C}$ ) were considered. It is seen from Figure 13 that the use of mist injection during the experiments did not yield any $\Delta \mathrm{T}_{\mathrm{HX}}$ greater than $15^{\circ} \mathrm{C}$, while, on the other hand, the use of a water shower in the IEC heat exchanger delivered temperature reductions across the IEC heat exchanger of at least $5{ }^{\circ} \mathrm{C}$.

The highest cooling demand on the DX cooling is, as expected, associated with the single-effect 'DX only' mode of operation. The highest cooling demand is reflected by the highest electrical energy consumption, equating to $15.78 \mathrm{kWh}$, of the FAHU. The next level of consumption occurs at the triple-effect 'DX with mist and water shower' mode, which consumes $13.61 \mathrm{kWh}$ when the FAHU operates with cooling contributions across the IEC heat exchanger of less than $10{ }^{\circ} \mathrm{C}$ and $5-10{ }^{\circ} \mathrm{C}$, respectively.

The lowest electrical energy consumption by the wet modes of operation, equating to $9.42 \mathrm{kWh}$, occurs with the dual-effect 'DX with water shower' mode of operation when there is a cooling benefit of at least $15^{\circ} \mathrm{C}$ across the IEC heat exchanger.

When the cooling contribution of the IEC heat exchanger is in the range $5-10{ }^{\circ} \mathrm{C}$, the triple-effect mode of operation consumes ( $16.3 \%$ and $22.6 \%$ ) more energy, respectively, than the dual-effect ${ }^{\prime} \mathrm{DX}$ with 
mist' and the dual-effect 'DX with water shower' modes of operation. When the IEC heat exchanger contribution is in the range $10-15^{\circ} \mathrm{C}$, it is found that the triple-effect 'DX with mist and water shower' requires $(14.3 \%)$ more energy than the dual-effect 'DX with mist' mode; and (11\%) more energy than the dual-effect mode 'DX with water shower' mode of operation. For $\Delta \mathrm{T}_{\mathrm{HX}}>15^{\circ} \mathrm{C}$, the triple-effect 'DX with mist and water shower' mode requires $22.6 \%$ more energy than that needed for the dual-effect 'DX with water shower' mode of operation.

It is interesting to note that the triple-effect 'DX with mist and water shower' consumes the same amount of power when $\Delta \mathrm{T}_{\mathrm{HX}}$ is less than $5^{\circ} \mathrm{C}$ as it does when $\Delta \mathrm{T}_{\mathrm{HX}}$ is in the range $5-10{ }^{\circ} \mathrm{C}$. The reason for the electrical energy consumptions being equal at two different values of $\Delta \mathrm{T}_{\mathrm{HX}}$ can is as follows. The temperature difference of the primary airstream across the IEC heat exchanger $\left(\Delta \mathrm{T}_{\mathrm{HX}}\right)$ represents only a sensible cooling load; hence, for the electrical consumption of the given mode of operation to remain the same at two different values of $\Delta \mathrm{T}_{\mathrm{HX}}$, the total cooling load of the FAHU must be the same for the two cases. This occurs because the latent loads imposed on the FAHU differ for the two values of $\Delta \mathrm{T}_{\mathrm{HX}}$. When compared to the single-effect 'DX only' mode, the best-performing wet mode of operation (dual-effect 'DX with water shower') in terms of electrical energy consumption saves $40.5 \%$ of the energy required by the single-effect 'DX only' mode of operation.

The coefficient of performance (COP) of the FAHU when operating in ambient dry-bulb temperatures greater than $40^{\circ} \mathrm{C}$ is calculated for an arbitrary average ambient condition of $47.8^{\circ} \mathrm{C}$ and $10 \% \mathrm{RH}$. The average ambient condition is selected by inspection of the available experimentally measured data. The results of the calculated COPs are presented in Table 4.

Table 4. COP calculated from experimental data for ambient temperatures greater than $40{ }^{\circ} \mathrm{C}$.

\begin{tabular}{cc}
\hline Mode of Operation & Coefficient of Performance (COP) \\
\hline DX & 2.48 \\
Combined DX + IEC & 3.94 \\
\hline
\end{tabular}

It is found that the use IEC in combination with DX cooling in temperatures greater than $40^{\circ} \mathrm{C}$ more than doubles the COP of the FAHU. The improvement in performance is due to the reduction in electrical energy consumption associated with the contribution of the sensible cooling provided by the IEC heat exchanger.

\section{Conclusions}

This study experimentally investigated the behavior of a hybrid FAHU integrating a vapor compression cooling cycle (DX) with IEC instigated by mist injection, water shower, or a combination of mist and water shower. The study compared different modes of operation in ambient conditions with dry-bulb temperatures less than $40^{\circ} \mathrm{C}$, as well as when ambient temperatures are higher than $40{ }^{\circ} \mathrm{C}$, as this has never been reported in the literature until now. The following conclusions were drawn:

(i) The difference in values of $\Delta \mathrm{T}_{\mathrm{HX}}$ between the best-performing mode of operation, i.e., triple-effect 'DX with mist and water shower' and the worst-performing mode (dual-effect 'DX with mist') decreases with increasing ambient relative humidity. The difference in values of $\Delta \mathrm{T}_{\mathrm{HX}}$ was found to be only $1{ }^{\circ} \mathrm{C}$ as the ambient relative humidity increased from $10 \% \mathrm{RH}$ to $50 \% \mathrm{RH}$.

(ii) The triple-effect 'DX with mist and water shower' achieves the highest temperature reductions across the IEC heat exchangers for ambient dry-bulb temperatures below and above $40^{\circ} \mathrm{C}$.

(iii) In certain ambient conditions, using a water shower achieves the same reduction in the temperature of the primary airstream across the IEC heat exchanger as does the use of a combination of mist and water shower.

(iv) In cases where a given mode of operation consumes the same amount of power when the cooling benefit across the IEC heat exchangers is different, a likely reason is the modulation or ramping down of the mist generator, as found in the present study. 
(v) For the harsh climatic conditions experienced in Qatar, the best-performing mode of operation of the FAHU achieves energy savings of $60.4 \%$ compared to cooling using vapor compression (DX), when ambient temperatures are below $40{ }^{\circ} \mathrm{C}$. The energy savings decrease to $40.5 \%$ when ambient temperatures are above $40^{\circ} \mathrm{C}$.

(vi) In ambient temperatures less than $40^{\circ} \mathrm{C}$, the COP of the FAHU is doubled when IEC is used in combination with DX cooling compared to using DX cooling by itself. Meanwhile, for ambient temperatures greater than $40^{\circ} \mathrm{C}$, the COP of the FAHU when using the 'triple-effect' DX with mist and water shower mode of operation is 2.16 times better than the single-effect DX only mode of operation.

The results of this study show that significant energy savings can be achieved by incorporating IEC cycles in fresh-air-handling units used in harsh climatic conditions such as those experienced in Qatar, where ambient temperatures rise above $45^{\circ} \mathrm{C}$ during summer periods.

Author Contributions: Conceptualization, Y.A.H.; Methodology, Y.A.H.; Software, Y.A.H. and B.T.; Validation, X.Y.A. and B.T.; Formal Analysis, Y.A.H., B.T. and N.C.; Investigation, Y.A.H., B.T. and M.M.; Resources, Y.A.H.; Data Curation, N.C. and M.M.; Writing-Original Draft Preparation, Y.A.H., B.T. and N.C.

Funding: This research received no external funding.

Conflicts of Interest: The authors declare no conflicts of interest.

\section{Nomenclature}

$\begin{array}{ll}\text { COP } & \text { Coefficient of performance } \\ \text { DX } & \text { Direct expansion } \\ \text { E/A } & \text { Extract air } \\ \text { EAF } & \text { Extract air fan } \\ \text { FAHU } & \text { Fresh-air-handling unit } \\ \text { FM } & \text { Flow meter } \\ \text { EC } & \text { Evaporative cooling } \\ \text { IEC } & \text { Indirect evaporative cooling } \\ \text { IDEC } & \text { Indirect/direct evaporative cooling } \\ \text { RH } & \text { Relative humidity } \\ \mathrm{Q}_{\mathrm{e}} & \text { Cooling capacity } \\ \mathrm{S} / \mathrm{A} & \text { Supply air } \\ \mathrm{SAF} & \text { Supply air fan } \\ \mathrm{T}_{\mathrm{db}} & \text { Dry-bulb temperature } \\ \mathrm{T}_{\mathrm{wb}} & \text { Wet-bulb temperature } \\ \mathrm{T} / \mathrm{H} & \text { Temperature and humidity sensor } \\ \mathrm{T} / \mathrm{S} & \text { Temperature sensor } \\ \Delta \mathrm{T} & \text { Temperature difference } \\ \Delta \mathrm{T}_{\mathrm{HX}} & \text { Temperature difference across heat exchanger } \\ \Delta \mathrm{T}_{\mathrm{DX}} & \text { Temperature difference DX cooling coil } \\ \mathrm{W}_{\mathrm{c}} & \text { Power input } \\ \end{array}$

\section{References}

1. Alshahrani, J.; Boait, P. Reducing High Energy Demand Associated with Air Conditioning Needs in Saudi Arabia. Energies 2019, 13, 87. [CrossRef]

2. Yu, F.W.; Ho, W.T.; Chan, K.T.; Sit, R.K.Y. Theoretical and experimental analyses of mist pre-cooling for an air-cooled chiller. Appl. Therm. Eng. 2018, 130, 112-119. [CrossRef]

3. Yang, J.; Chan, K.T.; Wu, X.; Yang, X.; Zhang, H. Performance enhancement of air-cooled chillers with water mist: Experimental and analytical investigation. Appl. Therm. Eng. 2012, 40, 114-120. [CrossRef]

4. Boukhanouf, R.; Ibrahim, H.G.; Alharbi, A.; Kanzari, M. Investigation of an evaporative cooler for buildings in hot and dry climates. J. Clean Energy Technol. 2014, 2, 221-225. [CrossRef] 
5. Al-Zubaydi, A.Y.T.; Hong, G. Experimental study of a novel water-spraying configuration in indirect evaporative cooling. Appl. Therm. Eng. 2019, 151, 283-293. [CrossRef]

6. Guo, X.C.; Zhao, T.S. A parametric study of an indirect evaporative air cooler. Int. Commun. Heat Mass Transf. 1998, 25, 217-226. [CrossRef]

7. Al Juwayhel, F.; El-Dessouky, H.; Ettouney, H.; Al-Qattan, M. Experimental evaluation of one, two and three-stage evaporative cooling systems. Heat Transf. Eng. 2004, 25, 72-86. [CrossRef]

8. De Antonellis, S.; Joppolo, C.M.; Liberati, P.; Milani, S. Experimental analysis of a cross-flow indirect evaporative cooling system. Energy Build. 2016, 121, 130-138. [CrossRef]

9. Suryawanshi, S.D.; Chordia, T.M.; Nenwani, N.; Bawaskar, H.; Yambal, S. Efficient technique of air-conditioning. In Proceedings of the World Congress on Engineering, London, UK, 6-8 July 2011; Volume iii.

10. De Antonellis, S.; Joppolo, C.M.; Leone, C.; Liberati, P.; Milani, S. Indirect evaporative cooling systems: An experimental analysis in summer condition. Energy Procedia 2017, 140, 467-474. [CrossRef]

11. Elakhdar, M.; Tashtoush, B.M.; Nehdi, E.; Kairouani, L. Thermodynamic analysis of a novel Ejector Enhanced Vapor Compression Refrigeration (EEVCR) cycle. Energy 2018, 163, 1217-1230. [CrossRef]

12. Megdouli, K.; Tashtoush, B.M.; Nahdi, E.; Kairouani, L.; Mhimid, A. Performance analysis of a combined vapor compression cycle and ejector cycle for refrigeration cogeneration. Int. J. Refrig. 2017, 74, 517-527. [CrossRef]

13. Cui, X.; Chua, K.J.; Yang, W.M. Use of indirect evaporative cooling as pre-cooling unit in humid tropical climate: An energy-saving technique. Energy Procedia 2014, 61, 176-179. [CrossRef]

14. Tashtoush, B.M.; Al-Nimr, M.; Khasawneh, M. A comprehensive review on ejector design, performance and applications. Appl. Energy 2019, 240, 138-172. [CrossRef]

15. Megdouli, K.; Tashtoush, B.M.; Ejemni, N.; Nahdi, E.; Mhimid, A.; Kairouani, L. Performance analysis of a new ejector expansion refrigeration cycle (NEERC) for power and cold: Exergy and energy points of view. Appl. Therm. Eng. 2017, 122,39-48. [CrossRef]

16. Tashtoush, B.; Almutaz, B.; Algharbawi, R. Parametric Study of a Novel Hybrid Solar Variable Geometry Ejector Cooling with Organic Rankine Cycles. Energy Convers. Manag. 2019, 198, 111910. [CrossRef]

17. Tashtoush, B.; Younes, M.B. Thermodynamic Analysis of a Solar Ejector Cooling System for Evaluation of High-Performance Environment friendly Refrigerant. Arab. J. Sci. Eng. 2019, 44, 1165-1185. [CrossRef]

18. Heidamnejad, G.; Bozorgmehr, M.; Delfani, S.; Esmaeelin, J. Experimetal investigation of two-stage indirect/direct evaporative cooling system. Build. Environ. 2009, 44, 2073-2079. [CrossRef]

19. Ghiabaklou, Z. Climatic range for comfort evaporative cooling. World Academy of Science, Engineering and Technology. Int. J. Archit. Environ. Eng. 2010, 4, 253-256.

20. Kim, M.H.; Jeong, J.W. Cooling performance of a $100 \%$ outdoor air system integrated with indirect and direct evaporative coolers. Energy 2013, 52, 245-257. [CrossRef]

21. Bruno, F. On-site experimental testing of a novel dew-point evaporative cooler. Energy Build. 2011, 43, 3475-3483. [CrossRef]

22. Porumb, B.; Balan, M.; Porumb, R. Potential of indirect evaporative cooling to reduce the energy consumption in fresh air conditioning applications. Energy Procedia 2016, 85, 433-441. [CrossRef]

23. Maheshwari, G.P.; Al Ragom, F.; Suri, R.K. Energy-saving potential of an indirect evaporative cooler. Appl. Energy 2001, 69, 69-76. [CrossRef]

24. Delfani, S.; Esmaeelian, J.; Pasdarshahri, H.; Karami, M. Energy saving potential of an indirect evaporative cooler as a pre-cooling unit for mechanical cooling systems in Iran. Energy Build. 2010, 42, 2169-2176. [CrossRef]

25. Chauhan, S.S.; Rajput, S.P.S. Parametric analysis of a combined dew-point evaporative-vapor compression-based air conditioning system. Alex. Eng. J. 2016, 55, 2333-2344. [CrossRef]

26. Tashtoush, B.; Al-Oqool, A. Factorial analysis and Experimental study of water-based cooling system effect on the performance of Photovoltaic module. Int. J. Environ. Sci. Technol. 2019, 16, 3645-3656. [CrossRef]

27. Tashtoush, B.; Tahat, M.; Al-Hayajneh, A.; Mazur, V.A.; Probert, D. Thermodynamic behavior of an air conditioning system employing combined evaporative-water air coolers. Appl. Energy 2001, 70, 305-319. [CrossRef]

28. Gomez, E.V.; Martinez, F.J.R.; Tejero, A. Experimental characterization of an indirect evaporative cooling prototype in two operating modes. Appl. Energy 2012, 97, 340-346. [CrossRef] 
29. Liberati, P.; De Antonellis, S.; Leone, C.; Joppolo, C.M.; Bawa, Y. Indirect evaporative cooling systems: Modeling and performance analysis. Energy Procedia 2017, 140, 475-485. [CrossRef]

30. De Antonellis, S.; Joppolo, C.M.; Liberati, P. Performance measurement of a cross-flow indirect evaporative cooler: Effect of water nozzles and airflows arrangement. Energy Build. 2019, 184, 114-121. [CrossRef]

31. Farnham, C.; Nakao, M.; Nishioka, M.; Nabeshima, M.; Mizuno, T. Effect of water temperature on evaporation of mist sprayed from a nozzle. J. Heat Isl. Inst. Int. 2015, 10, 35-44.

32. Bastakoti, N. Psychrometric analysis of indirect evaporative cooling based dedicated outdoor air system for Indian cities with different climatic conditions. Int. J. Eng. Res. 2018, 7, 187-189.

33. Chen, Y.; Luo, Y.; Yang, H. Fresh air pre-cooling and energy recovery by using indirect evaporative cooling in hot and humid region-A case study in Hong Kong. Energy Procedia 2014, 61, 126-130. [CrossRef]

34. Chauhan, S.S.; Rajput, S.P.S. Thermodynamic analysis of the evaporative-vapour compression based combined air conditioning system for hot and dry climatic conditions. J. Build. Eng. 2015, 4, 200-208. [CrossRef]

35. Morgado, B.I.; Melero, T.S.; Neila, G.J.; Acha, R.C. Evaporative cooling efficiency according to climate conditions. Procedia Eng. 2011, 21, 283-290.

36. Cui, X.; Chua, K.J.; Islam, M.R.; Ng, K.C. Performance evaluation of an indirect pre-cooling evaporative heat exchanger operating in hot and humid climate. Energy Convers. Manag. 2015, 102, 140-150. [CrossRef]

(C) 2019 by the authors. Licensee MDPI, Basel, Switzerland. This article is an open access article distributed under the terms and conditions of the Creative Commons Attribution (CC BY) license (http://creativecommons.org/licenses/by/4.0/). 